\title{
Program of training in abrazoterapia, to strengthen socio-affective skills in educators of municipal infantile centers
}

\begin{abstract}
Background: The purpose of the Training Program in Abrazotherapy is to strengthen Socio-affective Skills in Educators, which are the fundamental pillar to provide quality and warm care to children benefiting from Municipal Children's Centers. For this reason, it is postulated that the attention given must be affectionate, emphasizing an attachment relationship.
\end{abstract}

Methodology: The methodological theoretical approach is based on the scientific area of Positive Psychology, the action plan is through the design of pre-experimental research, with application of pre-test and post-test of the qualitative-quantitative measurement instrument, "Goldstein Social Skills Questionnaire ", supported by the Workshop on Abrazotherapy method, to a non-probabilistic representative sample of volunteer subjects (30 Educators from 15 Children's Centers of the Municipality of La Paz).

Results: The results obtained show that the Skills most developed by the Educators were for Stress Management, Alternatives to Aggression and Related to the Management of Feelings, this facilitated that each educator managed to improve their communication skills, recognize their own feelings, understand and express them, improving abilities and strategies of patience, respect and care for working with children and families, but above all and what is important for this work, the expression of affection.

Conclusions: The Abrazotherapy Training Program to strengthen the Socio-affective Skills becomes an effective tool in the process of labor and personal formation in the Educators.

Recommendations: It is recommended to implement the "Workshop of Abrazotherapy" within the induction process of all the educators and the activities of all the Municipal Children's Centers, so that educators, mothers and fathers recognize the importance of giving affection to the children, for its proper physical and mental development during early childhood.

Keywords: abrazotherapy, socioaffective skills, positive psychology, educators, early childhood
Volume 3 Issue 5 - 2018

Karina Veizaga Sangueza

Psychologist, Universidad Mayor de San Andrés-Bolivia, Bolivia

Correspondence: Karina Veizaga Sangueza, Psychologist, Universidad Mayor de San Andrés-Bolivia, Bolivia, Email krnveizaga@gmail.com

Received: May 08, 2018 | Published: September 05, 2018

\section{Introduction}

"With hugs, coats are woven for the soul ..." (Helen Maran, 2011) The purpose and scope of the Training Program in Abrazotherapy, is to strengthen the social and affective skills of educators, which are the fundamental pillar to provide quality care and warmth to children who come from families with limited economic resources and in situations of vulnerability, who are beneficiaries of the Municipal Children's Centers (CIM) of the City of La Paz. It is important to highlight the work of the educator, since it is in early childhood where forms and relationships are developed that greatly affect the degree of affectivity with which children interact in their environment. A volunteer group of 30 educators from 15 Municipal Children's Centers was selected, as a representative sample because there are cases of girls and boys referred and attended in the Psychology Area of the CIM. For this reason, this population was chosen to work on the importance of providing affection during early childhood.

The Training Program in Abrazotherapy is based on the Positive Psychology theory, postulated by the American psychologist Martin Seligman (1998), this well-known researcher decided to turn the trend of Psychology, which focused only on negative emotions and how treat them to focus on how to make people happy, that their level of well-being grows. Postulates that affect and positive emotions are important for people's happiness. After highlighting the need to investigate in a determined way the healthy aspects of the human being, he proposed the creation of Positive Psychology as a specific current within Psychology, studying real facts, the bases of psychological well-being and human strengths and virtues; Therefore, the importance of developing training programs. In this research we want to strengthen socio-affective skills, to generate feelings, positive feelings and a culture of pleasant hugs that provide confidence, happiness, belonging and protection in educators, who in turn worked the same dimensions with girls and boys beneficiaries and their respective families (mothers, fathers and/or guardians).

The design of this research is Pre-experimental, to measure the scope of the proposal and collect the data was applied the PreTest and Post-Test of the "Goldstein Social Skills Questionnaire", (6 groups of skills), supported by the Workshop method, as a tool for the development of Socio-affective Skills, carried out during 3 sessions on Abrazotherapy Training; Subsequently, the activities were 
carried out, since the educators included in the arrival and dismissal of the children to their Children's Center and within the educational planning by Sala the practice of the different Types of Hugs and their meaning, during the two-month span; and finally, the coordination of exhibitions on Abrazotherapy carried out by the trained educators aimed at mothers, parents and /or guardians of the girls and boys who are beneficiaries of the CIM, which was recorded in an Observation Guide and an "Abrazotherapy Questionnaire" for Parents ", prepared by the researcher.

The most relevant data show that the Skills most developed by the Educators were for Stress Management, Alternatives to Aggression and Related to the Management of Feelings, especially what was most important for the present investigation, is having achieved the expression of affection through the Types of Hugs (Bear Hug, Sandwich Hug, Cuddle to the Measure, Group Hug and Side Hug).

\section{Problem}

The Abrazoterapia, is an innovative technique of physical and affective regulation, the power that the hug has as a physical contact is not only something pleasant, it is something necessary, it is a therapy that rediscovers the importance of the embrace as a vital necessity that we all have, much more during early childhood . It is the practice of applying hugs in order to cure, and maintain health, because like laughter and music is one of the many tools that nature has given us; this simple and powerful natural and spontaneous act that is the embrace, is an example of which often what we need most is simple and priceless. Through "education", this simple and powerful natural and spontaneous act, which is the embrace, has been destroyed for a long time. We found references from an author who postulates that through the embrace and her art, relearning the "AbrazArte". We have bridges of embraces through which emotions circulate freely and rescue us from loneliness and isolation. It postulates that: "It is an innovative technique of physical-affective-emotional regulation that uses hugs in a literal and metaphorical way as a therapeutic instrument. ${ }^{1} 1$ in his book: "Abrazotherapy, the language of hugs ".

In as much, that the development of the Socio-affective Skills requires a work of measurement in which the potentialities of the interaction, of the adaptive conduct of the subject are used to the maximum; understand themselves, understand and tolerate others, manage emotions and behaviors or know how to relate healthy with their peers. Several authors have developed classifications to organize these skills in subgroups, areas or dimensions. In this line, a first approach to these skills was made by Howard Gardner.

Thus, the psychological support needs found in the Institution (Municipal Children's Centers), arises from the cases referred to the Psychology Area; cases of girls and boys with aggressive behavior, presence of shyness, isolation, inappropriate behaviors for the age, negligence and even mistreatment by parents or guardians, this type of behavior allows recognizing that these children live in an environment where They probably do not receive the adequate affective attention they need and it is important at this stage of their life (Early Childhood, 0 to 5 years), where they would also be violating the rights of children. For this reason, it is postulated that the attention given by the Educators to children must be affectionate, loving, emphasizing an attachment relationship and in that way provide a sense of wellbeing, through trust, happiness, belonging and protection. At the same time, that they come to interact adequately between co-workers and with the families of the children and beneficiaries. For this reason, the present investigation is born.

\section{Objectives}

\section{General purpose}

Strengthen the social and emotional skills of 30 educators of girls and boys from 3 to 5 years old beneficiaries of 15 Municipal Children's Centers, through the Training Program in Abrazotherapy.

\section{Specific objectives}

Analyze the social skills of 30 nursery and preschool teachers in 15 Municipal Children's Centers, by applying the pre-test and posttest of the "Goldstein Social Skills Questionnaire".

Promote affectivity, generating a culture of pleasant hugs in 15 Municipal Children's Centers, enabling 30 trained educators to implement the Abrazotherapy Program in daily activities and at the time of entry and exit of children from their Infant Centers.

Coordinate exhibitions with 30 educators trained in Abrazotherapy to organize the replica of the workshop, aimed at mothers, parents and/or guardians of children from Salas Infante and Preschool of 15 Municipal Children's Centers.

\section{Methodology}

The methodological theoretical approach is from the scientific area of Positive Psychology, the definitive impulse for the creation of positive psychology was given by the American psychologist Martin Seligman (1998) of the University of Pennsylvania and former Director of the American Psychological Association. The plan of action is through the design of pre-experimental research, with the obtaining of quali-quantitative data of pre-test and post-test with a single group. The proposal for the application of this Program is the method of the Workshop as a tool that becomes an essential part of the formation, in the lapse of 3 sessions, with the following topics proposed in each session: Module 1. About the Embrace and the Embraces, the Confidence Dimension and the first two groups of Social Skills (HH.SS from Start and Advanced HH.SS.) were worked; In Module 2. Types of Hugs, we worked on the Dimensions happiness and belonging and the Social Skills groups (HH.SS. Related to Handling Feelings and HH. SS. Alternatives to Aggression); and in Module 3. Say it with Hugs, we worked on the Dimension of PROTECTION and Social Skills (HH.SS.Estimates to Stress and HH.SS. of Planning). "Through the construction of a simplified model of reality is learned and the test of new behaviours, emotions and values that are committed to live a given situation. In addition to allowing the collective and cooperative construction of Advanced); In Module 2. Types of Hugs, we worked on the Dimensions HAPPINESS AND BELONGING and the Social Skills groups (HH.SS. Related to Handling Feelings and HH.SS. Alternatives to Aggression); and in Module 3. Dilo with hugs, protection dimension and social skills we worked (HH.SS. avoidant HH.SS. Stress and Planning). "Through the construction of a simplified model of reality is learned and the test of new behaviors, emotions and values that are committed to live a given situation. In addition to allowing the collective and cooperative construction of learnings. Otherwise, it is also built with psychological measuring instruments that facilitate the evaluation and training for the acquisition, strengthening or extinction of socially skillful behaviors of an individual or social group within the environment in which they find themselves ".

The type of sample for this study is of the type of empirical or representative samples, in turn they are divided into non-probabilistic 
samples; "It is one where the choice does not depend on the probability, but on causes related to the characteristics of the research and the decision of a researcher or group of interviewers". "This type of sample is used in studies where subjects are expected to be homogeneous in variables such as age, sex, intelligence, so that the results or effects do not obey individual differences, but the conditions to which they were subjected" The definition of this sample depends on the decision of the researcher, it is he who determines the number of subjects or elements of the sample. ${ }^{3}$ Mong this type of sample are the sample of volunteer subjects; this integrated by subjects who voluntarily access participate in a study. The choice of cases depends on fortuitous circumstances that the subjects accept to undergo the evaluations. Usually, this type of samples are conformed to carry out experimental studies. Tintaya P. ${ }^{4}$ As important data of the sample is that in Article 24 of the Municipal Regulation of Organization and Operation of Municipal Children's Centers, appointment: ARTICLE 24 (EDUCATORS BY CHILDREN'S CENTER). For attention to girls and boys, the table of the ratio of girls/boys by educator will be applied according to the following table: Relationship between number of girls, boys and educators The Program of Integral Attention in Early Childhood in the Municipality of La Paz, has a total of 63 CIM distributed in 6 Macrodistrict of the city of La Paz: Peripheral, Max Paredes, Cotahuma, Centro, San Antonio and Sur. The observation unit is made up of each one of the educators in their Work Room in their respective Children's Center, where they work from 8:30 am to 4:30 pm from Monday to Friday.

According to the table of the ratio of the number of girls, boys and female educators, the amount of CIM per Macrodistrict in the city of La Paz and the psychological needs observed, it was considered appropriate to apply the "Abrazotherapy Training Program to strengthen socio-affective skills ", in a non-probabilistic representative sample of 30 Volunteer Educators from Salas Infante and Pre-escolar (1 Educadora por Sala), of 15 CIM, most of them functional within Municipal Markets due to the great demand of attention to girls and boys of the selling ladies of the markets. The CIM chosen as the sampling frame were: "Camacho" Children's Center, "Los Andes" Children's Center, "Max Paredes" Children's Center, "Miraflores" Children's Center, "Alto 27 de Mayo" Children's Center, "Villa Nuevo Potosí" Children's Center. , "Virgen de Fátima" Children's Center, "8 de Diciembre" Children's Center, "Juancito Pinto" Children's Center, "Genoveva Ríos" Children's Center, "Lanza" Children's Center, "Rodríguez" Children's Center, "Villa 5 Findos" Children's Center, "Rosasani " Children's Center and "Kollasuyo "Children's Center .

For obtaining qualitative and quantitative data of pre-test and post-test of this research work, the self-applied questionnaire of Social Skills of Goldstein was used, its objective is to evaluate the deficits and effectiveness of each one of the Social Skills that They are mentioned in each question. The content consists of 50 questions that are written divided into 6 groups: 1. First Social Skills or Start Social Skills; 2. Advanced Social Skills; 3. Social Skills Related to Feelings; 4. Social Alternatives to Aggression; 5. avoidant social skills and 6. Social Stress planning skills. Each of these groups consists of a certain number of questions and spaces to place the difficulties that each individual presents when answering the Questionnaire. Each of them is called "Situation Problem". The general correction of this instrument is made by adding the values obtained in response to each statement. The responses shown are rated under the Likert scale of 5 points $(1=$ Never, $2=$ Very rarely, $3=$ Sometimes, $4=$ Often, $5=$ Always $)$. A subject can reach a maximum score of 250 points that are divided among the 50 items. In this way the average obtained by the subject is obtained. Subsequently, each group is averaged by the amount of social skills that each group comprises. The application time for filling it is 30 minutes.

To validate the Research Instrument, the "Goldstein Social Skills Questionnaire" was applied to a representative sample of 5 educators from the "Camacho" Children's Center, located on the third subsoil of the Municipal Market of the same name. It was explained to the educators that they would be given a Questionnaire of 50 questions, which they should answer in about half an hour. At the end of the term, the questionnaires were collected and the collaboration was appreciated. Once the answers were obtained, the data procedure was performed with the validation technique through the Reliability Coefficient. Alfa de Cronbach, according to George and Mallery (2003, p.231), cited by Barraza (2007: 8). The result of 0.93 was obtained, following the general criterion of George and Mallery of evaluation, it is specified that an EXCELLENT Alpha Coefficient result was obtained. The result indicates that the Test is not less than 0.9 and approaches 1, which in statistical terms means that the Questionnaire is valid. In this sense, it is also added that this measurement instrument, when assessing what is intended in the development of its content, achieves a reliability coefficient suitable for its application. Once the detailed answers have been obtained under this scale, we proceed to the respective application of Pre-Test and Post-Test, for tabulation and description of results in a qualitative and quantitative manner.

A brief Questionnaire for parents of family on Abrazoterapia was elaborated that consists in 5 questions, to be filled by the parents, after the exposition of the educators on the Workshop of Abrazoterapia , in each one of the 15 CIM. An Observation Guide was also prepared to record the work of each educator with the children of her Room (Infant and Preschool) and the mothers and fathers of family in the corresponding Municipal Children's Center.

\section{Development of the Proposal}

The procedure of sequence of Activities by Stages is divided:

\section{Stage I}

Selection of Municipal Children's Centers (15 CIM).

Selection of Educators (30 volunteer educators).

Validation of the Research Instrument " Goldstein Social Skills Questionnaire " prior to the Pre-Test and Post-Test.

Pre-Test application to 30 educators

\section{Stage 2}

Explanation of the "Training Program in Abrazotherapy to strengthen socio-affective skills in educators of girls and boys from 3 to 5 years beneficiaries of the Municipal Children's Centers", in a meeting scheduled for 30 educators.

Exhibition in 3 sessions of the Training Workshop in Abrazotherapy. First Session / Module 1. About the Embrace and the Embraces.

Second Session / Module 2. Types of Hugs.

Third Session / Module 3. Say it with Hugs.

\section{Stage 3}

Meeting with 30 educators trained after recess of activities in the 
Municipal Children's Centers.

Visits to 15 Municipal Children's Centers, to observe activities of educators with children from Salas "Infante" and "Pre-escolar".

\section{Stage 4}

Preparation of "Abrazotherapy Questionnaire for mothers and fathers of family".

Exhibition of the Abrazotherapy Workshop by trained educators and addressed to mothers, parents and / or tutors of 15 Municipal Children's Centers.

Application of the Post-Test to 30 educators.

Qualitative processing of the obtained data.

Quantitative processing of the data obtained.

Centralization of the information obtained.

Preparation of conclusions and recommendations.

\section{Results}

The present data is presented according to the qualitativequantitative analysis of the results obtained by Dimension registered in the Observation Guide filled in the visits to the $15 \mathrm{ClM}$. The impact that the Program had on the participants and their socio - affective abilities is studied to identify possible changes, especially the differences registered by the Educator, with the Pre-Test and Post-Test of the research instrument "Social Skills Questionnaire" of Goldstein. "The qualitative results of the "Abrazotherapy Questionnaire for mothers and fathers of families" are also presented.

\section{a. Results Cuali -quantitative Skills socioaffective by Dimension}

The framework of the Training Workshop on Abrazotherapy was carried out, with the records of the Observation Guide and the recordings of the exhibitions of the Abrazotherapy Workshop conducted by the educators and addressed to mothers, parents and / or guardians.

\section{Confidence dimension}

Interpretation: In the follow-up of the work of the CONFIDENCE Dimension (Social Skills of Beginning and Advanced Social Skills), of the 30 volunteer educators in 15 Municipal Children's Centers, it was registered in the Observation Guide; Participation with children and participation with mothers, parents and / or guardians. It was obtained that: 2 educators demonstrated to work with a minimum level of $6 \% ; 8$ educators demonstrated their work at a regular $27 \%$ level and 20 educators worked at a satisfactory level of $67 \%$ (Table 1) (Figure 1).

Table I Confidence dimension

\begin{tabular}{lll}
\hline \multicolumn{2}{l}{ Confidence dimension } \\
\hline Observation & Frequency & Percentage \\
\hline Minimum & 2 & $6 \%$ \\
Regular & 8 & $27 \%$ \\
Satisfactory & twenty & $67 \%$ \\
Total & 30 & $100 \%$ \\
\hline
\end{tabular}

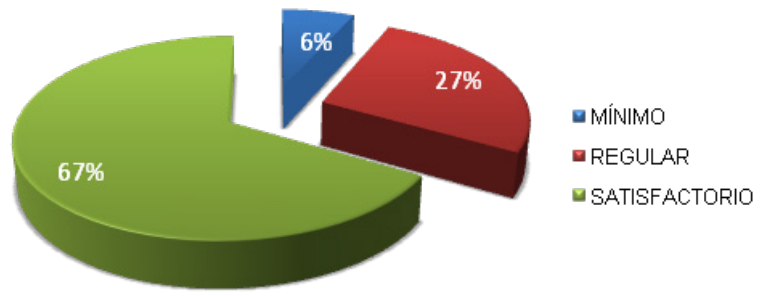

Figure I Dimension confidence.

\section{Happiness dimension}

Interpretation: The work of the 30 educators was monitored in the 15 selected Municipal Children's Centers of the Dimension HAPPINESS (Social Skills Related to Managing Feelings). They were recorded in the Observation Guide; Compliance with the Room and Conduct Activity of girls and boys. Obtaining the following results: no educator demonstrated working with a minimum level registering $0 \%$; 10 educators showed work at a regular level $33 \%$ and 20 educators worked at a satisfactory level67\% (Table 2) (Figure 2).

Table 2 Happiness dimension

\begin{tabular}{lll}
\hline \multicolumn{2}{l}{ Happiness dimension } \\
\hline Observation & Frequency & Percentage \\
\hline Minimum & 0 & $0 \%$ \\
Regular & 10 & $33 \%$ \\
Satisfactory & twenty & $67 \%$ \\
Total & 30 & $100 \%$ \\
\hline
\end{tabular}

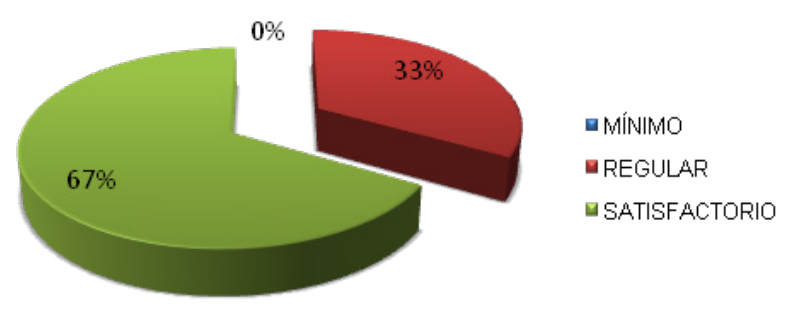

Figure 2 Dimension happiness.

\section{Dimension belonging}

Interpretation: The work of the 30 educators from the Dimension BELONGING (Alternatives to Aggression Social Skills) was followed with the records in the Observation Guide of the Types of Hugs made, taking into account the frequency observed in the visits to the 15 Municipal Children's Centers: first, the frequency of the types of hugs carried out by the educators with the girls and boys in their corresponding rooms (infant and pre-school), second, the frequency of hugs carried out among girls and boys and finally the frequency of hugs of mothers, parents and / or guardians with the girls and boys at the moment of the entrance and exit of the infants to their corresponding Infant Center. The types of hugs most replicated by the educators were: Bear Hug, Sandwich Embrace and Embrace the Measure with $12 \%$ frequency; Group hug with $10 \%$ frequency; Embrace Side with 9\%; Hug in A-shape with 8\%; Impetuous hug with $7 \%$; Hug Head with 6\%; Embrace of Cheek, Back and Heart with 5\%; and Embrace of Ankle, of Guessing and Zen with 3\% of frequency replicated in the CIM in both working rooms of the educators (Table 3) (Figure 3). 
Table 3 Membership dimension

\begin{tabular}{|c|c|c|c|c|c|c|}
\hline No & Type of hug & $\begin{array}{l}\text { Frequency (among } \\
\text { educators, girls / children) }\end{array}$ & $\begin{array}{l}\text { Frequency } \\
\text { (between girls } \\
\text { and children) }\end{array}$ & $\begin{array}{l}\text { Frequency (among mothers, } \\
\text { parents and / or guardians, } \\
\text { girls / children) }\end{array}$ & $\begin{array}{l}\text { Total } \\
\text { frequency }\end{array}$ & Percentage \\
\hline I & Bear hug & fifteen & fifteen & fifteen & Four. Five & $12 \%$ \\
\hline 2 & $\begin{array}{l}\text { Hug with a } \\
\text { shape }\end{array}$ & 12 & 12 & 5 & 29 & $8 \%$ \\
\hline 3 & Cheek embrace & 5 & 5 & 10 & twenty & $5 \%$ \\
\hline 4 & Sandwich hug & fifteen & fifteen & fifteen & Four. Five & $12 \%$ \\
\hline 5 & Impetuous hug & 10 & 7 & 10 & 27 & $7 \%$ \\
\hline 6 & Group hug & fifteen & fifteen & 10 & 40 & $10 \%$ \\
\hline 7 & Side hug & 12 & 12 & 12 & 36 & $9 \%$ \\
\hline 8 & $\begin{array}{l}\text { Hug for the } \\
\text { back }\end{array}$ & 8 & 8 & 4 & twenty & $5 \%$ \\
\hline 9 & Hug of heart & 7 & 7 & 4 & 18 & $5 \%$ \\
\hline 10 & Hug to measure & fifteen & fifteen & fifteen & Four. Five & $12 \%$ \\
\hline II & Ankle embrace & 7 & 0 & 5 & 12 & $3 \%$ \\
\hline 12 & $\begin{array}{l}\text { Hug of } \\
\text { adivinance }\end{array}$ & 5 & 5 & 0 & 10 & $3 \%$ \\
\hline 13 & Head embrace & 12 & 5 & 5 & 22 & $6 \%$ \\
\hline 14 & Zen hug & 5 & 5 & 0 & 10 & $3 \%$ \\
\hline
\end{tabular}

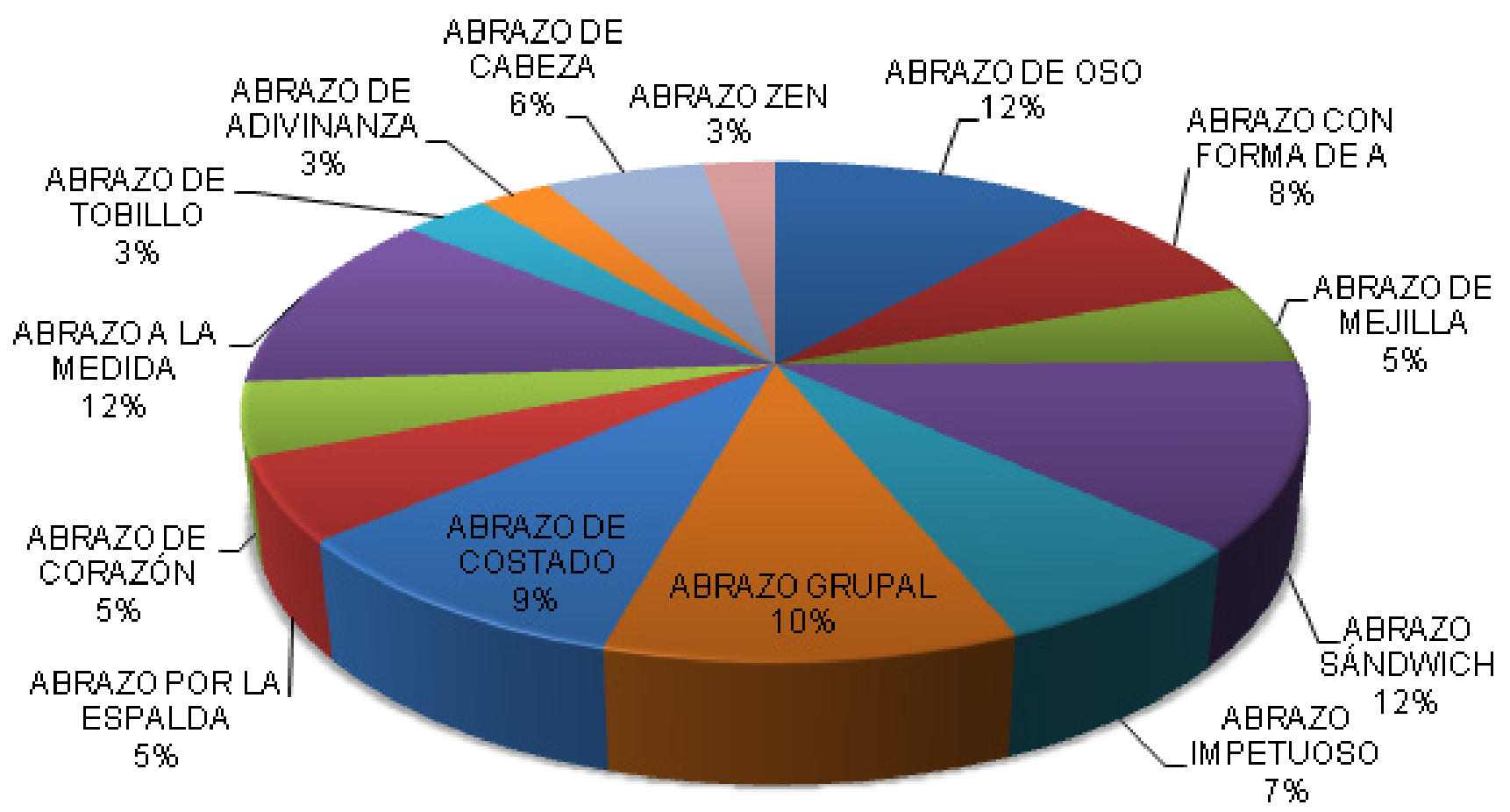

Figure 3 Membership dimension.

Citation: Sangueza KV. Program of training in abrazoterapia, to strengthen socio-affective skills in educators of municipal infantile centers. Int Phys Med Rehab J. 2018;3(5):360-372. DOI: 10.15406/ipmrj.2018.03.00129 


\section{Protection dimension}

Interpretation: In the exhibition of the Abrazotherapy Training Workshop conducted by the educators and addressed to mothers, fathers and / or guardians, the group of Social Skills Avoidance of Stress and Social Skills of Planning was worked on). The follow-up was done with the records of the Observation Guide on the Exhibition of the Workshop and Compliance with Activity in the Room. Obtaining the following results: 1 educator demonstrated to work the exhibition with a minimum level of $3 \% ; 5$ educators demonstrated working at a regular level of $17 \%$ and 24 educators worked on the exhibition of the Workshop on Abrazotherapy at a satisfactory level of $80 \%$ (Table 4) (Figure 4).

Table 4 Protection dimension

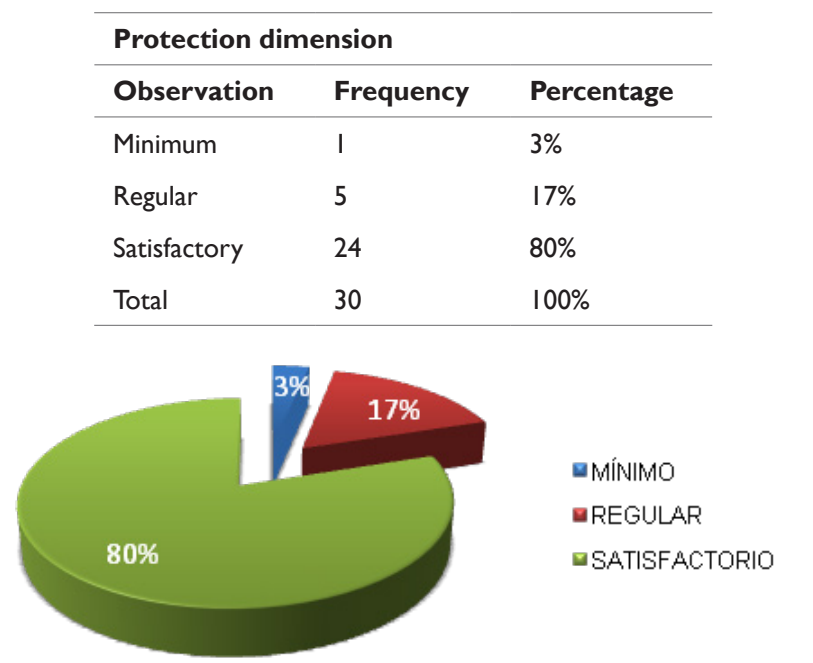

Figure 4 Protection dimension.

\section{b. Results Cuali -quantitative pretest and post-test by Municipal Children 's Center}

Interpretation: The general correction of this instrument is made by adding the values obtained in response to each statement. A subject can reach a maximum score of 250 points that are divided among the 50 items. In this way, the average obtained by the Municipal Children's Center is obtained. The results of the Pretest of the " Goldstein Social Skills Questionnaire " applied to 30 educators, in 15 Municipal Children's Centers, ranges from 147.59 points to 232.85 points (only 2 decimals are taken into consideration). The results of the Post-Test indicate that the average score of educators ranges from 212.77 points to 241.45 points. In general, an increase in the Social Skills of the educators is observed. Being that in the Children's Center in which greater results were obtained was in the Children's Center "Camacho", which obtained a percentage variance of $49 \%$ and in the Children's Center where lower results were obtained in the Children's Center "Juancito Pinto" obtained a percentage variance of 3\% (Table 5) (Figure 5).

Quali -quantitative results of "Abrazoterapia Questionnaire for mothers and parents"

Interpretation: The questionnaire was applied to mothers, parents and/or guardians attending the meetings scheduled for the exhibition of the Workshop on Abrazotherapy made by the 30 Educators who were trained in the Infant and Pre-school Rooms of each of the 15 Centers Children's Municipal. It was filled by 308 people, of
415 registered as the beneficiary population of the CIM, since the meetings scheduled by the educators were not attended by all the mothers, parents and/or tutors, there were some absences in almost all the Municipal Children's Centers and it was considered convenient to add the total population of both working rooms of the Educators and only divide the surveyed population by women and men, for the qualitative analysis. There were a total of 200 women among mothers, aunts, sisters and grandmothers who filled out the Questionnaire and 108 men among parents, uncles and grandparents who filled out the "Abrazotherapy Questionnaire" (Table 6) (Table 7) (Table 8) (Table 9) (Table 10) (Table 11).

Table 5 General results of pre-test and post-test by municipal children's center

\begin{tabular}{|c|c|c|c|c|c|}
\hline No & $\begin{array}{l}\text { Children's } \\
\text { center }\end{array}$ & Pre-proof & Post test & Difference & Var\% \\
\hline I & Dec-08 & $18,64,879$ & 221.8874 & $3,53,995$ & $19 \%$ \\
\hline 2 & $\begin{array}{l}\text { High may } \\
27\end{array}$ & 199.2889 & $23,43,198$ & $3,50,309$ & $18 \%$ \\
\hline 3 & Camacho & $14,75,933$ & 220.2353 & $7,26,420$ & $49 \%$ \\
\hline 4 & $\begin{array}{l}\text { Genoveva } \\
\text { rios }\end{array}$ & 196.952 & $21,27,700$ & $\mathrm{I}, 58, \mathrm{I} 28$ & $8 \%$ \\
\hline 5 & $\begin{array}{l}\text { Juancito } \\
\text { pinto }\end{array}$ & $21,78,853$ & $22,39,82$ I & 6.0968 & $3 \%$ \\
\hline 6 & Kollasuyo & 191.5026 & $23,30,278$ & $4,15,252$ & $22 \%$ \\
\hline 7 & Spear & $18,50,135$ & $22,15,495$ & $3,65,361$ & twenty\% \\
\hline 8 & The andes & $|6,99,47|$ & 214.6543 & $4,47,072$ & $26 \%$ \\
\hline 9 & $\begin{array}{l}\text { Max } \\
\text { paredes }\end{array}$ & $17,94,3 \mid 8$ & 235.9958 & $5,65,640$ & $32 \%$ \\
\hline 10 & Miraflores & $19,65,888$ & 213.9953 & I,74,065 & $9 \%$ \\
\hline II & Rodriguez & 207.4988 & $22,81,838$ & 20.685 & $10 \%$ \\
\hline 12 & Rosasani & $23,28,455$ & $24,14,493$ & 86,038 & $4 \%$ \\
\hline 13 & $\begin{array}{l}\text { Villa } 5 \\
\text { fingers }\end{array}$ & $2|, 68,34|$ & $23,84,990$ & $2,16,649$ & $10 \%$ \\
\hline 14 & $\begin{array}{l}\text { Villa nuevo } \\
\text { potosi }\end{array}$ & $|8,63,9| 4$ & $22,62,517$ & $3,98,602$ & $\begin{array}{l}\text { twenty- } \\
\text { one\% }\end{array}$ \\
\hline 15 & $\begin{array}{l}\text { Virgin of } \\
\text { fatima }\end{array}$ & $20,24,118$ & $22,63,664$ & $2,39,547$ & $12 \%$ \\
\hline
\end{tabular}

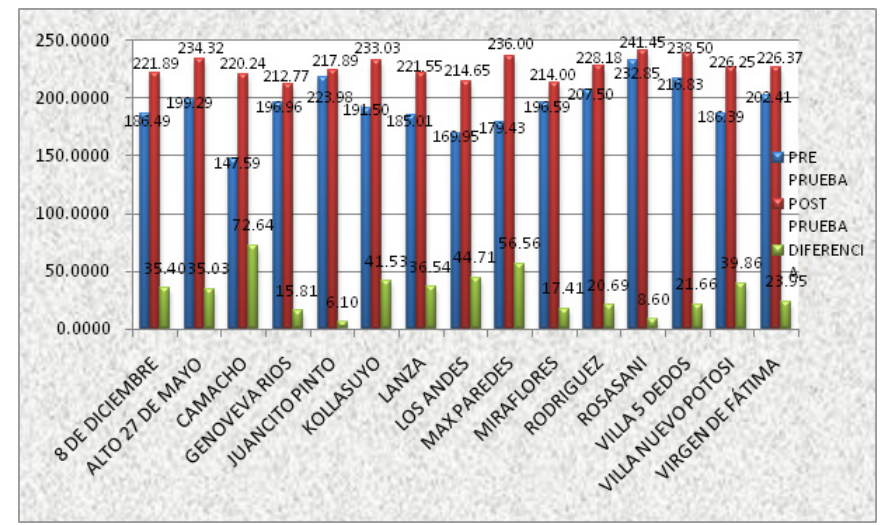

Figure 5 General Results of Pre-Test and Post-Test by Municipal Children's Center. 
Table 6 Quantitative results of the " abrazotherapy questionnaire for mothers and fathers of family"

\begin{tabular}{|c|c|c|c|c|c|}
\hline \multirow[t]{2}{*}{ No } & \multirow[t]{2}{*}{ Municipal childhood center } & \multicolumn{2}{|l|}{ Infant rooms and pre-school } & \multicolumn{2}{|c|}{$\begin{array}{l}\text { Population filling the } \\
\text { questionnaire }\end{array}$} \\
\hline & & $\begin{array}{l}\text { Number of girls / children } \\
\text { beneficiaries }\end{array}$ & $\begin{array}{l}\text { Quantity of mothers, parents } \\
\text { and / or guardians }\end{array}$ & Women & Mens \\
\hline I & Dec-08 & 10 & 18 & 10 & 4 \\
\hline 2 & High may 27 & 12 & 22 & 12 & 4 \\
\hline 3 & Camacho & Twenty & 30 & 22 & 10 \\
\hline 4 & Genoveva rios & 18 & 28 & 16 & 12 \\
\hline 5 & Juancito pinto & 16 & 32 & 10 & 10 \\
\hline 6 & Kollasuyo & 12 & 22 & 7 & 4 \\
\hline 7 & Spear & Twenty & 40 & Twenty & 12 \\
\hline 8 & The andes & 19 & 39 & 10 & 8 \\
\hline 9 & Max paredes & 18 & Twenty & Eleven & 8 \\
\hline 10 & Miraflores & 18 & 28 & Fifteen & 6 \\
\hline II & Rodriguez & 19 & 37 & 14 & 8 \\
\hline 12 & Rosasani & 12 & 26 & 8 & 4 \\
\hline 13 & Villa 5 fingers & 14 & 25 & 17 & 5 \\
\hline 14 & Villa nuevo potosi & 18 & 28 & 19 & 7 \\
\hline 15 & Virgin of fatima & 16 & Twenty & 9 & 6 \\
\hline \multicolumn{2}{|c|}{ Total } & 242 & 415 & $\begin{array}{l}200 \\
308\end{array}$ & 108 \\
\hline
\end{tabular}

Table 7 Qualitative Results

\begin{tabular}{|c|c|c|}
\hline Children's center & Answers & Population \\
\hline \multirow{2}{*}{ Dec-08 } & "It is the show of affection through a hug" & Family Guy \\
\hline & "That is a way of giving affection and consolidating ties" & Mother of family \\
\hline \multirow{2}{*}{ High may 27} & "It's demonstrating a tender feeling in a physical way" & Grandfather \\
\hline & "Happiness" & Aunt \\
\hline \multirow{2}{*}{ Camacho } & "Exercise in which we raise self-esteem through hugs" & Mother of family \\
\hline & "It is giving love, affection, expression of feelings" & Mother of family \\
\hline \multirow{2}{*}{ Genoveva rios } & "It is giving affection to a person" & Mother of family \\
\hline & "Affected" & Grandmother \\
\hline \multirow{2}{*}{ Juancito pinto } & "The affection that is transmitted" & Family Guy \\
\hline & "What is a feeling, is a cure for loneliness" & Mother of family \\
\hline \multirow{2}{*}{ Kollasuyo } & "It's feeling something unique" & Sister \\
\hline & "Have a session of diverse hugs between several people" & Family Guy \\
\hline \multirow{2}{*}{ Spear } & $\begin{array}{l}\text { "It is a hugging therapy with which we reinforce and stimulate the } \\
\text { growth of our children" }\end{array}$ & Family Guy \\
\hline & $\begin{array}{l}\text { "It is using the hug to give more security to our children and to } \\
\text { grow up happy" }\end{array}$ & Mother of family \\
\hline \multirow{2}{*}{ The andes } & "It's improving the mood with hugs" & Mother of family \\
\hline & "We can relieve pain or loneliness with a strong hug" & Mother of family \\
\hline
\end{tabular}


Table continued..

\begin{tabular}{|c|c|c|}
\hline Children's center & Answers & Population \\
\hline \multirow{2}{*}{ Max paredes } & "It is to strengthen family ties and friendship" & Mother of family \\
\hline & "Work security and family belonging" & Aunt \\
\hline \multirow{2}{*}{ Miraflores } & "It's a way to get closer to our children and make them feel happy" & Family Guy \\
\hline & "It's working with different hugs at home" & Grandmother \\
\hline \multirow[b]{2}{*}{ Rodriguez } & "It is to feel something unique, that provides positive experiences" & Mother of family \\
\hline & $\begin{array}{l}\text { "Moms and dads we can work with Abrazoterapia , to give } \\
\text { happiness to the children" }\end{array}$ & Mother of family \\
\hline \multirow{2}{*}{ Rosasani } & "It's improving self-esteem" & Mother of family \\
\hline & "It is to provide protection, safety, health, joy, and a lot of love" & Mother of family \\
\hline \multirow{2}{*}{ Villa 5 fingers } & "It's doing therapy through hugs" & Family Guy \\
\hline & "It's giving hugs to those who need it" & Mother of family \\
\hline \multirow{2}{*}{ Villa nuevo potosi } & $\begin{array}{l}\text { "You can bring happiness with lots of hugs that show affection for } \\
\text { the children" }\end{array}$ & Mother of family \\
\hline & "Give hugs to make our children feel safe" & Family Guy \\
\hline \multirow{2}{*}{ Virgin of fatima } & "It is to improve the coexistence in our home" & Mother of family \\
\hline & "We can give our children happiness with hugs" & Mother of family \\
\hline
\end{tabular}

Question I In your words that you understand by Abrazoterapia?

Table 8 Qualitative Results

\begin{tabular}{|c|c|c|}
\hline Children's center & Answers & Population \\
\hline \multirow{2}{*}{ Dec-08 } & "Bear hug, side, group" & Grandfather \\
\hline & "Group hug, hug of three, hug heart" & Mother of family \\
\hline \multirow{2}{*}{ High may 27} & "Cheek, back, bear" & Mother of family \\
\hline & "Bear, heart, riddle, group, sandwich, back, impetuous" & Family Guy \\
\hline \multirow{2}{*}{ Camacho } & "The bear hug, the group hug, head" & Mother of family \\
\hline & "Bear hug, heart hug, group hug" & Mother of family \\
\hline \multirow{2}{*}{ Genoveva rios } & "Of heart, of three, of cheek" & Mother of family \\
\hline & "Hug back, bear, three" & Family Guy \\
\hline \multirow{2}{*}{ Juancito pinto } & "The one of heart, the one of three, in A" & Mother of family \\
\hline & "Bear, group, sandwich" & Family Guy \\
\hline \multirow{2}{*}{ Kollasuyo } & "The bear, the group, the sandwich" & Grandmother \\
\hline & "Bear, sandwich, group" & Mother of family \\
\hline \multirow{2}{*}{ Spear } & "Sandwich, group, couple" & Family Guy \\
\hline & "Bear hug, custom, sandwich" & Mother of family \\
\hline \multirow{2}{*}{ The andes } & "Bear hugs, heart, group" & Aunt \\
\hline & "Group, heart, bear" & Family Guy \\
\hline \multirow{2}{*}{ Max paredes } & "Riddle, bear, sandwich" & Family Guy \\
\hline & "Bear hug, impetuous, custom" & Mother of family \\
\hline \multirow{2}{*}{ Miraflores } & "The bear hug, sideways, custom" & Mother of family \\
\hline & "The hug of heart, of bear, group" & Mother of family \\
\hline \multirow{2}{*}{ Rodriguez } & "Bear hug, hug to size, hug the cheek" & Mother of family \\
\hline & "E-shaped hug, custom, heart and bear also" & Mother of family \\
\hline \multirow{2}{*}{ Rosasani } & "Bear hug, group, hug to size" & Family Guy \\
\hline & "Bear hugs, custom and heart" & Mother of family \\
\hline
\end{tabular}




\begin{tabular}{lll}
\hline Table continued... & & Population \\
\hline Children's center & Answers & Mother of family \\
\hline Villa 5 fingers & "Bear, sandwich, group, impetuous, custom" & Mother of family \\
Villa nuevo potosi & "Hug sandwich, group hug, bear hug" & Mother of family \\
Virgin of fatima & "The hugs of heart, custom and group" & Family Guy \\
& "Bear hug, heart hug, group hug" & Mother of family \\
\hline
\end{tabular}

Question 2 What types of hugs do you like the most?

Table 9 Qualitative Results

\begin{tabular}{|c|c|c|}
\hline Children's center & Answers & Population \\
\hline \multirow{2}{*}{ December-08 } & "Group and the bear" & Family Guy \\
\hline & "Hug of three, hug of heart, Hug of bear, hug of cheek" & Mother of family \\
\hline \multirow{2}{*}{ High may 27} & "Bear with my children and my baby Raquel" & Family Guy \\
\hline & "The bear hug because he is the most affectionate" & Mother of family \\
\hline \multirow{2}{*}{ Camacho } & "The bear" & Mother of family \\
\hline & "Embrace of three" & Mother of family \\
\hline \multirow{2}{*}{ Genoveva rios } & "Everybody" & Family Guy \\
\hline & "The group and the cheek" & Mother of family \\
\hline \multirow{2}{*}{ Juancito pinto } & "Bear hug" & Family Guy \\
\hline & "The bear, the group and the sandwich" & Family Guy \\
\hline \multirow{2}{*}{ Kollasuyo } & "The bear hug" & Mother of family \\
\hline & "Group, couple" & Family Guy \\
\hline \multirow{2}{*}{ Spear } & "Bear, because we're just my daughter and I" & Mother of family \\
\hline & "Bear hug" & Mother of family \\
\hline \multirow{2}{*}{ The andes } & "The hug sandwich, I liked it better" & Mother of family \\
\hline & "The group hug" & Mother of family \\
\hline \multirow{2}{*}{ Max paredes } & "Bear and riddle" & Mother of family \\
\hline & "Embrace of heart" & Mother of family \\
\hline \multirow{2}{*}{ Miraflores } & "Hugs of heart, custom and three" & Mother of family \\
\hline & "I would practice all the hugs" & Mother of family \\
\hline \multirow{2}{*}{ Rodriguez } & "Bear hug" & Mother of family \\
\hline & "The bear, the group, and the back hug with my wife" & Family Guy \\
\hline \multirow{2}{*}{ Rosasani } & "The bear hug and the cheek hug" & Mother of family \\
\hline & "Bear hug" & Mother of family \\
\hline \multirow{2}{*}{ Villa 5 fingers } & "The hug sandwich, I liked it better" & Mother of family \\
\hline & "The group hug" & Mother of family \\
\hline \multirow{2}{*}{ Villa nuevo potosi } & "Bear and riddle" & Mother of family \\
\hline & "Embrace of heart" & Family Guy \\
\hline \multirow{2}{*}{ Virgin of fatima } & "Bear hug" & Mother of family \\
\hline & "The hug of group and couple" & Family Guy \\
\hline
\end{tabular}

Question 3 What kind of hug would you practice at home, with your family? 
Table 10 Qualitative Results

\begin{tabular}{|c|c|c|}
\hline Children's center & Answers & Population \\
\hline \multirow{3}{*}{ Dec-08 } & "They are very good people and it's good that they know about these issues" & Mother of family \\
\hline & & \\
\hline & "It's a nice experience you share with parents" & Mother of family \\
\hline \multirow{3}{*}{ High may 27} & "It will help my daughter a lot, what I learned" & Mother of family \\
\hline & & \\
\hline & "It seems very nice and nice" & Mother of family \\
\hline \multirow{3}{*}{ Camacho } & "That the experience is very good" & Mother of family \\
\hline & & \\
\hline & "Very good" & Uncle \\
\hline \multirow{3}{*}{ Genoveva rios } & "It was very concise and easy to understand" & Family Guy \\
\hline & & \\
\hline & "I think it is very useful to improve the relationship with our children" & Mother of family \\
\hline \multirow{3}{*}{ Juancito pinto } & "It's one of the most beautiful workshops l've been given" & Mother of family \\
\hline & & \\
\hline & "It's very good that they teach us these things, since not many of us have this habit" & Mother of family \\
\hline \multirow{3}{*}{ Kollasuyo } & "I found it very useful and practical" & Family Guy \\
\hline & & \\
\hline & "That is very constructive for both children and parents" & Mother of family \\
\hline \multirow{3}{*}{ Spear } & "It was time for educators to give us a topic of this importance" & Mother of family \\
\hline & & \\
\hline & "It was a very nice topic that was taught" & Mother of family \\
\hline \multirow{3}{*}{ The andes } & "Congratulate the Children's Center and the educators for imparting this theme" & Mother of family \\
\hline & & \\
\hline & "I loved it" & Family Guy \\
\hline \multirow{3}{*}{ Max paredes } & "It would be good if they gave us the written information" & Mother of family \\
\hline & & \\
\hline & "My congratulations to the educators" & Mother of family \\
\hline \multirow{3}{*}{ Miraflores } & "Thank the educators" & Mother of family \\
\hline & & \\
\hline & "That is something useful for my whole family" & Family Guy \\
\hline \multirow{3}{*}{ Rodriguez } & "It was a nice initiative, hopefully it will be repeated" & Mother of family \\
\hline & & \\
\hline & "I wish they would give more talks of this nature every so often" & Mother of family \\
\hline \multirow{3}{*}{ Rosasani } & "It is good that educators talk to us about important things like this Workshop" & Mother of family \\
\hline & & \\
\hline & "The educators of the Center are very prepared" & Mother of family \\
\hline \multirow{3}{*}{ Villa 5 fingers } & "It's a very nice experience" & Mother of family \\
\hline & & \\
\hline & "I think it was an exceptional workshop for its simplicity and importance" & Grandfather \\
\hline \multirow[b]{2}{*}{ Villa nuevo potosi } & "Just to thank the educators" & Mother of family \\
\hline & $\begin{array}{l}\text { "I found it entertaining, I had a good time, and if it has that effect, it's because the subject is } \\
\text { quite good" }\end{array}$ & Family Guy \\
\hline Virgin of fatima & "I would recommend that they give the Workshop again" & Mother of family \\
\hline
\end{tabular}

Question 4 What is your opinion about the Workshop given by the educators in your daughter's and / or child's room?. 
Table I I Qualitative results

\begin{tabular}{|c|c|c|}
\hline $\begin{array}{l}\text { Children's } \\
\text { center }\end{array}$ & Answers & Population \\
\hline \multirow{2}{*}{ Dec-08 } & "Maybe give us presentation in Power Point to have it in USB" & Mother of family \\
\hline & "It was a very beautiful and quite useful workshop" & Mother of family \\
\hline \multirow{2}{*}{ High may 27} & "That these workshops are more followed, that they are useful for everyone" & Mother of family \\
\hline & "Simple and practical. I congratulate the educators " & Grandmother \\
\hline \multirow{2}{*}{ Camacho } & "That they continue with the workshops to the parents" & Mother of family \\
\hline & "I would like other workshops to take place, to deepen the theme" & Mother of family \\
\hline \multirow{2}{*}{ Genoveva rios } & "Practice it at least once every 2 weeks" & Mother of family \\
\hline & "None, because I thought it was very good" & Family Guy \\
\hline \multirow{2}{*}{ Juancito pinto } & "I liked it so much, that I will start practicing what I learned at home" & Mother of family \\
\hline & "Remind us that we should always hug our children" & Family Guy \\
\hline \multirow{2}{*}{ Kollasuyo } & "Sounds good to me" & Aunt \\
\hline & "Let the Workshop be longer" & Mother of family \\
\hline \multirow{2}{*}{ Spear } & "Any" & Family Guy \\
\hline & "Practice saying goodbye to the meetings of the Children's Center with a group hug" & Mother of family \\
\hline \multirow[b]{2}{*}{ The andes } & "Let them be earlier and more often" & Mother of family \\
\hline & "I wonder, when do not give hugs? For example, if my son is reneging " & $\begin{array}{l}\text { Family father and } \\
\text { uncle }\end{array}$ \\
\hline \multirow{2}{*}{ Max paredes } & "Remind us that we should always hug our children" & Mother of family \\
\hline & "Because they do not hold workshops like this more often" & Mother of family \\
\hline \multirow{2}{*}{ Miraflores } & "None because they explained and did participate" & Aunt \\
\hline & "Very useful and important what the educators exhibited" & Mother of family \\
\hline \multirow{2}{*}{ Rodriguez } & "It will be very important to practice what I have learned with my children and my wife" & Family Guy \\
\hline & "I have no suggestions, everything was fine" & Family Guy \\
\hline \multirow[t]{2}{*}{ Rosasani } & $\begin{array}{l}\text { "It was very simple, and it was good but I would like you to explain us more in detail, since } \\
\text { it is a very interesting topic" }\end{array}$ & Mother of family \\
\hline & "It's very good, especially because we will practice it at the Children's Center" & Mother of family \\
\hline \multirow{2}{*}{ Villa 5 fingers } & "I would like more information" & Mother of family \\
\hline & "Very nice, very beautiful, and above all important" & Mother of family \\
\hline \multirow[b]{2}{*}{$\begin{array}{l}\text { Villa nuevo } \\
\text { potosi }\end{array}$} & "Expand the contents" & Mother of family \\
\hline & $\begin{array}{l}\text { "I am convinced that the information provided to parents will be very well received } \\
\text { and I would ask that the educators not only work on this issue this time, but all the } \\
\text { management" }\end{array}$ & Family Guy \\
\hline \multirow{2}{*}{ Virgin of fatima } & "Very important, I would have liked my son to be present in this Workshop" & Grandfather \\
\hline & "Just congratulate the Children's Center and above all congratulate the educators" & Mother of family \\
\hline
\end{tabular}

Question 5 What suggestion could you give, regarding the contents provided in the Abrazotherapy Workshop ?.

\section{Interpretation}

In the present qualitative analysis of the "Questionnaire on Abrazotherapy for mothers and fathers of family", applied to mothers, fathers and/or tutors, the most significant responses are expressed within the tables of each of the 5 questions, being a sample of the comments made by the mothers and fathers of the 15 Municipal Children's Centers. This allows us to observe that the topic proposed in the research work was well accepted by the population to which it was addressed, demonstrating the Socio - affective Skills of the educators, who were strengthened through the Training Workshop on Abrazotherapy, demonstrating the benefits provided by The
Abrazotherapy for the well-being of people and demonstrate that it is possible to generate a culture of pleasant hugs and above all the importance of working on the subject during early childhood. Of these exhibitions, most of the mothers and fathers of the family expressed their gratitude and appreciation for the dissertation of the topic..$^{5-19}$

\section{Conclusion}

The objectives proposed in this study were satisfactorily fulfilled, with the application of the "Training Program in Abrazotherapy", as well as the application of the instruments, a series of data has been collected that allow to raise the following conclusions: 
i. A research topic was developed, with a social impact, which may be applicable in the reality of the current context. The "Abrazotherapy Training Program" was applied for seven months, during which the educators developed a socially skilled behavior with affective tools.

ii. The Social Skills that the Educators developed the most were for Stress Management, Alternatives to Aggression and Related to the Management of Feelings, this facilitated that each educator is known, valued and accepted; that develops its level of communication and acquires confidence in itself, but above all and what was more important for the present investigation, the expression of affection. This means that they were able to improve their communication skills, recognize their own feelings, understand them and express them, since they showed companionship among them.

iii. Each educator is responsible for contributing in a positive way in the physical and mental development during the early childhood of the beneficiary girls and boys, of the Municipal Children's Centers, for this reason is that each volunteer educator was trained to guarantee an improvement in the quality of the work they provide in 15 Municipal Children's Centers.

iv. Emphasis was placed on the search for information that supports the scientific theory of the benefits of Abrazotherapy. Experiments were found at an international level that support the benefit in physical and mental development by the segregation of the hormones oxytocin and somatotropin, evidencing that there is a close relationship between the brain and hugs.

v. It is also important to mention that without being a specific objective in this work, the Training Program in Abrazotherapy influenced the strengthening of self-esteem, empathy and assertive communication of educators. Those who reflected on the treatment they receive and give themselves to parents and understand that each of them is the emotional bond between mothers, fathers and their daughters and sons.

vi. The "Abrazotherapy Training Program" is an effective tool to develop socio-affective skills in educators, since it allows them to develop skills and strategies of patience, respect and care for working with children from early childhood and also for the appropriate communication with parents. Therefore, it is concluded that it was possible to strengthen the Social and Affective Skills of 30 municipal educators.

vii. The mothers and fathers of the families of the children benefiting from the Municipal Children's Centers were committed to the proper physical and mental development of their daughters and sons and they practice hugging as a manifestation of affection, and of protection.

It was achieved that the educators will implement the Abrazotherapy Program in the daily activities of the Infant and PreSchool Rooms to promote a culture of pleasant hugs in the children of 15 Municipal Children's Centers. Since in the visits made to these Children's Centers, it was observed that the attention given by the Educators to the children is affectionate, emphasizing in an attachment relationship, and in that way providing a feeling of well-being, confidence, happiness, belonging and protection, which were the dimensions that were worked on in the present study. The Workshops in Abrazotherapy were carried out in the 15 Municipal Children's Centers: which were programmed and exposed by the educators previously trained, and support was given to them.

\section{Recommendations}

Based on the rationale, the authors' support and the results obtained in the present study, the following recommendations are made:

It is recommended to teach the theme of the "Abrazotherapy Training Program" within the activities of all Municipal Children's Centers, so that educators, mothers and fathers recognize the importance of giving affection to girls and boys, for their proper physical development and mental. This is fundamental if one considers that managing affectivity, negative emotions, and aggressive behaviors are generally inadequately learned from social, family, school, and other models. In this sense, the following is suggested:

Implement the "Workshop of Abrazotherapy", in the induction process of the educators of the Municipal Children's Centers, to strengthen the socio-affective skills of the same.

Organize workshop courses on socio-affective skills (Abrazotherapy Workshops), aimed at parents of children benefiting from Municipal Children's Centers, in such a way that work will be done to contribute to the positive development of these, guaranteeing that they grow in an environment conducive so that they can develop the skills and aptitudes that they possess.

It was recommended to parents in the 15 Municipal Children's Centers that they will practice what they learned in the Abrazotherapy Workshop daily until it becomes a habit, due to the importance in the physical and emotional development that it implies for their daughters, children and even for themselves. And when dismissing them and picking them up from the Children's Centers they do it with the kind of hug they would have liked the most.

Likewise, it is recommended that the educators continue cordially requesting mothers, parents and / or guardians, to say goodbye and pick up the children of the CIM with a hug.

\section{Acknowledgements}

None.

\section{Conflict of interest}

The author declares no conflict of interests.

\section{References}

1. Barberry L. The Language of Hugs. Spain: Mandala. 2007.

2. Hernández S. Collaborators. Research Methodology. Mac Graw-Hill Interamericana. Colombia. 1998;134.

3. Hernández S, Fernández C, Baptista L. Research Methodology, Mac Graw-Hill Interamericana, Colombia, 1998;227.

4. Tintaya P. Research Project, Bolivia: IEB. 2008.

5. Celeiro S, Golobardes M. Emotional Intelligence. Practical Guide for Parents and Educators. Spain: Ed. Tagus. 2013.

6. De zubiria M. Affectivity: The oldest of all mental functions". Colombia, 2013.

7. Gardner H. Multiple Intelligences. Barcelona: Paidós, 1995.

8. Goldstein A. Social skills and self-control. Spain-Barcelona: Martinez Roca. 1980

9. Goleman D. The Emotional Intelligence. Buenos Aires: Ed. Javier Vergara. 1997.

10. Keating K. Hold me. Argentina: Javier Vergara Editor SA, 1986;7-20. 
11. Keating K. Hug me 2. Argentina: Javier Vergara Editor SA,1988;24-67.

12. Monjas I. Social interaction skills teaching program for pre-school children" Madrid: CEPE. 1999.

13. Program of integral attention in the first childhood in the municipality of la paz. Institutional Documents, Childhood and Adolescence Unit GAMLP, La Paz-Bolivia. 200.

14. Municipal regulation of organization and functioning of the infantile centers of the municipality of la paz. Institutional Documents, Childhood and Adolescence Unit GAMLP, La Paz-Bolivia. 2002.
15. Seligman M. The real happiness. United States: Editions B. 2002

16. Seligman M. Guide The five steps to happiness. United States: Pennsylvania. 2011.

17. Sepúlveda C. Abrazoterapia. Colombia, 2007;38-40.

18. Serrano P. Training Program in Social Skills to improve the social climate in the Municipal Government of El Alto". UMSA, T-264. La Paz, Bolivia. 2005.

19. Vegas E, Santibañez L. Guide to human development in early childhood. Spain: Uranus, 2009. 